\title{
Sociolinguistics Background Determining Linguistic Politeness
}

\author{
Shokhikhatul Khasanah \\ Sekolah Tinggi Ilmu Syari'ah Nuruddhalam \\ (Email: sofiaalhaidari@gmail.com)
}

\section{Key Words:}

Sociolinguistics, Politeness.
ABSTRACT

This article is intended to show that Sociolinguistics background influences linguistic behavior among people. The way people communicate with other is vary based on their Sociolinguistics background; included the way to show Politeness. Thus, the difference Sociolinguistics background will determine the linguistic Politeness. Politeness is a concept which seeks to give respect to other when we are speaking. Some Sociolinguistics back-grounds that determine Linguistic Politeness, such as: power relationship and social distance, education, social status, job profession, gender, and ethnicity.

\section{Kata Kunci:}

Latar belakang sosial budaya, kesopanan berbahasa

\section{ABSTRAK}

Penelitian ini bertujuan untuk menunjukkan bahwa latar belakang sosial budaya mempengaruhi perilaku berbahasa. Cara manusia berkomunikasi dengan orang lain berbeda-beda sesuai dengan latar belakang sosial mereka, termasuk di dalamnya cara menunjukkan kesopanan. Jadi, perbedaan latar belakang sosial budaya akan menentukan kesopanan berba-hasa. Kesopanan berbahasa merupakan suatu konsep yang bertujuan untuk memberikan apre-siasi/penghormatan kepada orang lain saat berbicara. Beberapa latar belakang sosial yang menentukan tingkat kesopanan berbahasa, diantaranya: tingkat/kadar hubungan dan jarak so-sial, pendidikan, status sosial, pekerjaan, jenis kelamin dan etnis.
Shokhikhatul Khasanah

Sociolinguistics Background Determining Linguistic Politeness
(16)

ALSUNA Vol. 2 (1), 2019

http://e-journal.ikhac.ac.id/index.php/alsuna https://doi.org/10.31538/alsuna 


\section{Introduction}

Being polite is a complicated business in any language. It is difficult to learn because it involves understanding not just the social and cultural value of the community. We often don't appreciate just how complicated it is, because we tend to think of politeness simply as a matter of saying please and thank you in the right places. In fact; it involves a great deal more than the superficial politeness routines that parents explicitly teach their children. Generally speaking politeness involves taking account of the feeling of others. A polite person makes others feeling comfortable. Being linguistically polite involves speaking to people appropri-ately in the light on our relationship. Inappropriate linguistic choices may be considered rude.

Defining polite behavior is not quite as easy as we might think. When people asked what they imagine polite behavior to be there is a surprising amount of disagreement. So does when we talk about polite language we will encounter the same type of problems. To characterize polite language usage we may refer to the language a person uses to avoid being too direct or language, which displays respects toward, or consideration for others. We might gives examples such as language, which contains respectful forms of address like sir or madam, language that displays certain polite formulaic utterances like: Please, thank you, excuse me or sorry or even elegantly expressed language.

Politeness is not something we are born with but something we have to learn and be socialized into and no generation has beer; short of teachers and handbooks on etiquette and correct behavior to help us acquire polite skills. Again it seems that whether or not a particular's behavior is evaluated as polite or impolite is not merely a matter of the linguistics expression that she or he uses but rather depends on the interpretation of that behavior in social interaction.

As we have noted before that in speaking a language we must consider the communicative use or speech event in which the language is used. And because speech events regularly include a speaker and writer, listener and reader, it is not surprising that language is particularly sensitive in the rules for speech use to the relation between the two parties. So the choice of an appropriate message form can be modified to express a wide range of attitudes of the speaker to the listener. Geertz $(1960 ; 248)$ says it is nearly impossible to say anything without indicating

Shokhikhatul Khasanah

Sociolinguistics Background Determining

Linguistic Politeness http://e-journal.ikhac.ac.id/index.php/alsuna https://doi.org/10.31538/alsuna 
the social relationship between the speaker and the listener in terms of status and familiarity. So far when we talk about politeness we will pertain to the attitude of the speaker to the listener, in this case, politeness will consist of the recognition of the listener and his or her right in the situation.

\section{Sociolinguistics}

Sociolinguists study the relationship between language and society. They are interested in explaining why we speak differently in different social context, and they are concerned with identifying the social functions of language and the ways it is used to convey social meaning (Holmes, 2001). In line with that definition, Oxford Dictionary defines Sociolinguistics as the study of the language in relation to social factors, including differences of regional, class, and occupational dialect, gender differences, and bilingualism. Understanding and being able to implement social rules in communication are parts of communicative competence that consist of linguistic competence, discourse competence and sociolinguistic competence (Canale and Swain, 1982). In addition, Mukminatien (2003) defines sociolinguistic competence as the ability to choose language appropriately based on its context. In line with the statement above, sociolinguistic competence is the task faced by teacher-students and student-student in their interaction, i.e. learning how to use language appropriately for a variety of functions in a wide range of different situations.

Cameron (1995: 15-16) remarks: Whereas sociolinguistics would say that the way I use language reflects or marks my identity as a particular kind of social subject - I talk like a white middle-class woman because I am (already) a white middle-class woman .The critical account suggests language is one of the things that constitutes my identity as a particular kind of subject. Sociolinguistics says that how you act depends on who you are; critical theory says that who you are (and are taken to be) depends on how you act.

\section{Politeness}

The theories of politeness include those inspired by Lakoff (1973b) which presented subject-maxims used by speakers of a language, guiding their use of politeness. The three basic maxims proposed were of formal politeness (not imposing on others), informal polite-ness

Shokhikhatul Khasanah

Sociolinguistics Background Determining

Linguistic Politeness
(18)

http://e-journal.ikhac.ac.id/index.php/alsuna https://doi.org/10.31538/alsuna 
(giving options) and intimate politeness (striving to make the addressee feel good). Brown and Levinson's (1987) theory incorporates Lakoff's maxims into a much broader the-ory, giving one of the most influential and comprehensive studies of politeness to date (Fraser 1990 and Thomas 1995).

Brown and Levinson base their studies on Goffman's (1967, cited in Brown and Levinson 1987, 61) notion of face and the phenomenon of losing face, or becoming embarrassed or humiliated. They claim all interactants have a positive image of themselves and a desire for approval (positive face) and negative face, which they describe as 'the basic claim to territo-ries, personal preserves and right to non-distraction- i.e. to freedom of action and freedom from imposition' (Brown and Levinson 1987, 61).

Two different types of politeness

1) Positive Politeness: This is a series of strategies used to maintain a person's positive face by showing solidarity or friendship. It emphasized shared attitudes and value; minimising status differences. Positive politeness strategies include avoiding disagreement, seeking agreement, indicating common ground, being optimistic and intending to communicate that the speaker's wants are similar to those of the hearer, for example 'You look thirsty. Let's have a cup of tea'.

2) Negative Politeness: Negative politeness pays on people respect and avoids intruding of them. It involves expressing oneself appropriately in terms of social distance and respecting status differences. It is used to maintain the hearer's negative face by minimising imposition or intrusion into their space and characterized by notions of indirectness, hedging and softening. An example of indirectness might involve the use of apologies 'I'm sorry to impose but would you mind getting me a drink?'

In their highly influential cross-linguistic analysis of politeness conventions in language, Brown and Levinson (1987: 60-1) argue that politeness in language is centered on the notion of face - "the public self-image that every member wants to claim for himself" - and the ef-forts made by interlocutors to "maintain each other's face."

Shokhikhatul Khasanah

Sociolinguistics Background Determining

Linguistic Politeness
(19)

http://e-journal.ikhac.ac.id/index.php/alsuna https://doi.org/10.31538/alsuna 
Polite usage of language comes into play whenever a speaker has the potential to produce a face-threatening act (FTA), an utterance that undermines the tacit under-standing that all language should preserve face. In determining the exact level of politeness that will be employed to mitigate an FTA, Brown and Levinson (1987: 15) propose three considerations: the power relationships existing between speakers, their social distance, and the level of impoliteness that the FTA would create.

A theory of linguistic politeness should take as its focus the ways in which the members of a social group conceptualize politeness as they participate in socio-communicative verbal communication. Watts (2003:10) says that the term 'politeness' means something rather different from our everyday understanding of it and focuses almost uniquely on polite language in the study of verbal interaction. While Eelen (2001) points out, quite rightly that theories of politeness have focused far more on polite behavior than on impolite behavior. Politeness it-self is socially prescribed.

\section{Sociolingistics Backgrounds Determining Politeness}

\section{Power relationship and social distance}

In any social group, there will be differing power relationships among people. In a classroom, for instance, there will be a disparate power relationship between teacher and students: the teacher will be a super-ordinate (i.e. higher on the power hierarchy) and the students' subordinates (i.e. lower on the hierarchy). Most of the students will be equals; no power; imbalance will exist between them. However, even among students, it is possible to find dispar-ate relationships if, for instance, students form study groups, and one or more students in the groups hold power over the others. Whether individuals are disparate or equals will affect how they communicate. Students may use honorifics such as Professor or Doctor to address their teachers as a way of explicitly marking the disparate power relationship that exists be-tween a student and a teacher. For example: Selamat pagi, Pak Profesor Andrian. Bagaimana kabar Bapak?

In contrast, students may use their first names to address one another as a way of indicat-ing that they are equals. For instance: Pa kabar, Rika? Kamu sekarang tinggal di mana?.

Shokhikhatul Khasanah

Sociolinguistics Background Determining

Linguistic Politeness
(20)

\footnotetext{
http://e-journal.ikhac.ac.id/index.php/alsuna
} https://doi.org/10.31538/alsuna 
English has other titles used as honorifics (e.g. Miss, Ms, Sir, Madam, General, Colonel, President, Prime Minister, and Officer) as well as terms of address that have very restricted uses: Your hono (u) r sir and madam (which in Southern American English can be shortened to ma'am, your honor $(u) r$ used in a court of law to address a judge. Sir and madam (ma'am) are found in face-to-face conversations where speakers are disparate and the subordinate wants to show a high degree of deference to the other. These expressions are also found in the salutation of highly formal letters. In the examples below, sir and ma'am are used by servers to address customers in a restaurant. For example:

Have you been helped,Sir? And what did you want Ma'am?

Or in Indonesian context, let's consider this example:

Selamat malam, ini menu restoran kami, Silakan Tuan pesan sesuai keinginan. Selamat menikmati hidangan di restoran kami Nyonya, semoga berkenan.

In personal letters, in contrast, people tend to address each other by first name, an indication that both writer and addressee are equals and that little social distance separates them. For example:

Dear John, A day of hectic activity. Julie and I took Emily and her 2 boys who are aged 5 and nearly 3 swimming this morning ...

Social distance specifies the extent to which individuals have a close or a more distant relationship. Although the notions of social distance and power relationships are related disparate, for instance, tend to be more socially distant from one another than equals - the categories are nevertheless distinct. While all communicants will be either equals or disparate, some may be

Intimates as well. Close intimates will often use terms of endearment. For example:

Oh honey, I miss you (oh saying, aku kangen kamu)

How are you my little-one?( apa kabar kesayanganku satu2nya?)

Come here sweetheart (mendekatlah sayang)

Shokhikhatul Khasanah

Sociolinguistics Background Determining

Linguistic Politeness
(21)

\footnotetext{
http://e-journal.ikhac.ac.id/index.php/alsuna https://doi.org/10.31538/alsuna
} 
Their topics of conversation will vary too. Intimates are more likely to talk about family, health issues, and problems than non-intimates. The conversation below, for instance, would only occur between intimates, since it deals with very personal topics: familial problems, suicide, divorce and remarriage. As the social distance between speakers increases, the greater the requirement for polite usage of language: calling one's boss sweetheart, for instance, is likely to be perceived as highly inappropriate and impolite, Unless the boss and employee know each other well and over time have developed a close relationship.

It is clear that the words people use and the topics they discuss are in large part determined by their social relationships: whether they are disparate, equals, or intimates. However, in many languages, these relationships affect the choice of second person pronouns as well. When there is greater social distance. English, however, makes no such distinction: the pro-noun you is used in all contexts, regardless of the power relationships existing between speakers or their social distance. At one time in its history, English did make the distinction. As Blake (1992: 536) notes, although usage was inconsistent, during the Middle English pe-riod, thou and thee were used to denote "intimacy or contempt," while ye and you "were neu-tral and polite.

\section{Social status}

The way people express their politeness usually implies from what certain social status or from a certain group they are belong to. This is to say that, consciously or unconsciously we will more easily identify that someone from a high-class status, respectful family or low class status by identifying the language they chosen. Consider the language evidence given here:

"Mohon maaf, minta tolong rokoknya bisa dimatikan sebentar? Saya bersama si kecil"

"Mbok jangan ngrokok, ada anak kecil ini lho"

If we look at the first sentence we can guess that the sentence used by people of highclass status, while the second sentence tends to be used by ordinary people or people of low status. In these contexts, they are different languages form used by the speaker, which give us clues about their social background. The high-class people prefer to excuse/apologize in their speech act in order to ask people to do something/ request. In other settings; low classes pre-fer to use direct imperative to ask people to do something. Another example: a lower class people

Shokhikhatul Khasanah

Sociolinguistics Background Determining

Linguistic Politeness

\footnotetext{
http://e-journal.ikhac.ac.id/index.php/alsuna
} https://doi.org/10.31538/alsuna 
may say "Keluar saja kalo mau ngrokok!" while the high class people will say " Mohon maa, ini area bebas rokok. Jika anda ingin merokok, silakan meninggalkan ruangan". Here, the former use direct imperative as an order. While the latter use declarative and excuse showing the politeness; and stilling many examples, which distinguish the linguistic politeness, used by high class and the low class people.

\section{Education}

Education also plays an important role to produce and symbolized politeness in society. Well-educated people usually consider more polite than those who are non well-educated. In fact, well-educated people have access to comprehensible input and right exposure to be "po-lite group" from the environment they lived. School, teacher, lecture, books and other sources may facilitate them to speak politely. They showed Politeness by the choice of word, language form, attitude toward word, and even intonation. Consider the following sentence:

"Meskipun telah lama bekerja, mereka masih belum bisa membeli mobil karena financial management yang kurang tepat"

"Kerjo pirang-pirang tahun kok tuku mobil wae ra hiso, dileg wae po ket biyen?"

Actually the two different languages; that presented in Indonesian and Javanese convey the same meaning, that is; about person that still can't afford to buy a car even though he/she has been working for many years. By identifying the linguistic feature, such as the diction and speech act; we can identify whether those two sentence are spoken in polite or impolite way, in low or high intonation, in positive or negative attitude. Then, we immediately know who the speaker was, whether he/she was well-educated or non well-educated. Furthermore, it leads us to assess what level of education he/she belongs to or has no education at all.

Here if we seek to compare well- educated and non well-educated people, the way they the two groups speak are also different. What important in this point is that well-educated people tend to use indirectness. They frequently change or insert to another code by choosing the appropriate word word when they speak. Otherwise, non well-educated people rarely insert and change into another code when they speak. They tend to use direct speech act and merely used their own language. This is because they have different background in education.

Shokhikhatul Khasanah

Sociolinguistics Background Determining

Linguistic Politeness http://e-journal.ikhac.ac.id/index.php/alsuna https://doi.org/10.31538/alsuna 


\section{Job Profession}

Another Sociolinguistics background that determines linguistic politeness is job profession. The kind of politeness used give us clues that someone belongs to certain job profession; Pedicab drivers, farmer, lectures, businessman, executive, managers, etc.. Consider the following example:

"Lek gak mergo duik, lapo raine wong2 iku gelem ae di pampang ndik pinggir2 embong. Njajal lek ganok popo trus fotone moro2 di pampang ngunu iku, mosok yo gak protes, misuh2. Tapi polane urusan duik yo gelem ae wong2 iku. Golek duik kabeh caleg2iku. Gaweane ngobral janji, mbijuk'i'.

"Seandainya bukan demi kepentingan, mungkin para caleg itu tidak bersedia jika wajah mereka di pajang di pinggir jalan, tapi karena adanya kepentingan maka mereka permisive saat fotonya di pajang di pinggir jalan. Itu dilakukan sebagai bentuk sosialisasi untuk memperkenalkan diri, mendapatkan dukungan dan meraih simpati masyarakat serta meraup suara terbanyak agar di pilih, meski mereka sering mengobral janji dan membohongi rakyat"

From the example above we really believe that in certain situation there are clear differences between one who are from one profession with one from other profession. There are words or phrases that could be used by one profession only and it is not available on the language of other professions. The diction chosen, the direct/indirectness, the arrangement of the sentence in the first sentence differ from the second language. The former speaker seems arbitrary while the latter seems chronologically and systematically arranged. It happened be-cause the two sentences were expressed by different professions that lead their linguistic po-liteness different. Here, we can see clearly that social background that exposes their daily lives influence the linguistic behavior included linguistic politeness. The language form, the diction, and the attitude show that they are a pedicab driver, farmer, teacher, professor, bank staff and so forth.

Shokhikhatul Khasanah

Sociolinguistics Background Determining

Linguistic Politeness
(24)

http://e-journal.ikhac.ac.id/index.php/alsuna https://doi.org/10.31538/alsuna 


\section{Position}

Roles of someone in a certain setting influence the linguistic politeness. People who play an important role in a community or in a company even in a country will talk rather different from one who doesn't have a role. For example, the language used by presidents is different from that of ordinary people.

In addition, people who are superior that dominate a group (leader) or people who play as a majority in certain social life will also speak differently from those who are not regard as a superior, leader or majority in a group. We can find many varieties of linguistic politeness based on the position have.

\section{Gender}

There are some claims of the sort that 'women are more polite than men' - more polite than whom, to whom, about what and in what circumstances? Brown and Levinson (1987) take contextual factors into consideration, but it seems less clear how the differences in the two contexts above could be accounted for in relation to their social dimensions of relative power and social distance between speaker and hearer, and the ranking of impositions in a particular culture.

There have been many studies into the role politeness plays in different contextual situations. A study by Culpeper (1996) looks into the discourse in the arena of an army training camp, arguing that acts which directly attack face, rather than lead to communication breakdown, which Brown and Levinson predict, are actually essential in preventing this break-down, ensuring the efficiency of the operation. O'Barr and Atkins (1980) discuss similar finding in their investigation on 'women's language' in the courtroom. Holmes (1995) refers to the use of 'challenging' question tags in the police force to actually 'boost the force of a negative speech act' thus intensifying the loss of face, adding that rather than being a polite-ness strategy this can be seen as an impoliteness strategy.

In other words, do women speak more politely because they are female, or does po-lite language usage define one as a female? In addition, gender is not simply a biological phenomenon; it is an ideology as well that is tied in very closely with sexual identity: whether

Shokhikhatul Khasanah

Sociolinguistics Background Determining

Linguistic Politeness
(25)

\footnotetext{
http://e-journal.ikhac.ac.id/index.php/alsuna https://doi.org/10.31538/alsuna
} 
one is heterosexual, gay, lesbian, bisexual, or transgendered. Thus, when sociolinguists make claims about how males and females use language, it is important to realize that their conclusions reflect a significant simplification of the effect of gender on language usage. But de-spite this simplification, and the complexity inherent in speaker variables, it is nevertheless the case that how individuals speak is directly influenced by the speaker variables that define them.

\section{Ethnicity}

Ethnicity is a sensitive issue to be discussed as a part of sociolinguistic background that determines the linguistic politeness. People tend to choose the right word to communi-cate well and to show how polite they were. Politeness among ethnics are varies, depend on social acceptance. Often; the speech act used, direct or indirectness, imperative, declarative, expressive, excuse/apologize, gratitude and so on are used to measure the level of politeness.. Certain linguistic behavior can identify people that they come from certain member of ethnics or group, such as: Madurese, Javanese, Bataknese, Sundanese, etc.

As the example, Madurese are generalized as impolite ethnic consider the directness they used. Madurese prefer to speak directly and use high intonation to express their ideas or deliver their speech. While for some society's interpretations, Central Javanese are categorized as polite ethnic since they tend to speak indirect and use low intonation to express their ideas and deliver their speech. The diction and the attitude toward language indeed influence linguistic politeness that leads them to identify themselves to certain group.

\section{Conclusion}

Communication is not simply the product of decoding the words in a sentence or utterance and then determining their meaning. People should learn how to use language appropriately for a variety of functions in a wide range of different situations. They should consider certain social factors- who they are talking to, the social context of the talk, the function and the topic of discussion should be turn out to be important in accounting for language choice in many different kinds of speech community. This makes sense that there will be certain factors

Shokhikhatul Khasanah

Sociolinguistics Background Determining

Linguistic Politeness
(26)

http://e-journal.ikhac.ac.id/index.php/alsuna https://doi.org/10.31538/alsuna 
that affect the choice of language used when people communicate to imply the politeness and appropriateness in a communication.

Making decision about what is or is not considered polite in any community therefore involves assessing social relationship along the dimension of social distance or solidarity, formality and relative power or status. We need to understand the social values of a society in order to speak politely.

Many factors must be taken into consideration when determining an individuals or groups of individuals' use of linguistic politeness. It may not be entirely correct to suggest that politeness may be determined just one of these factors, such as gender. Factors that may be involved in determining our use of politeness strategies are: gender; age; our use of syntax (for example, tag question); the context of the situation in which we are interacting; the role of participants in the conversation and the extent of the loss of face to the addressee.

Other factors must be taken into account, such as context, age, and the role of participants. Certain social factors have been relevant in determining the linguistic politeness. Some relate to the users of language-the participants, the social setting and function of the interac-tion (who is talking to whom; e.g.-husband-wife/ boss-worker and etc.), setting and social context (e.g. home, school, work and etc.), the aim of the interaction (informative, directive and etc) and the topic (what is being talked about).

Many linguistic forms have complex function. They are used differently in different context. They mean different things according to their pronunciation, their position in the utterance, what kind of speech act they are modifying, and who is using them and to whom in what context. Like tags, they are often being used as politeness devices rather than as expression.

Last, very often no one speaker variable can adequately explain the use of a particular linguistic item: one variable works hand in hand with another. But despite the overlapping nature of the variables, some variables, such as ethnicity, are so powerful that they alone can have a significant effect on language usage and uncertainty.

Shokhikhatul Khasanah

Sociolinguistics Background Determining

Linguistic Politeness
(27)

\footnotetext{
http://e-journal.ikhac.ac.id/index.php/alsuna
} https://doi.org/10.31538/alsuna 


\section{Bibliography}

Bell, A. The Language of News Media. Blackwell, 1991.

Bonvillain, N. Language, Culture, and Communication: The Meaning of Messag-es. Prentice-Hall, 1993.

Brown, P. 'How and Why women are more polite: Some Evidence from a Malayan Community'. In McConnell-Ginet, Borker and Furman, 111-149, 1980.

Brown, P. and S. Levinson, Politeness: Some Universals in Language Usage. Cambridge University Press, 1987.

Cameron, D., F. McAlinden and K. O'Leary. 'Lakoff in context: the social and linguistic function of tag questions' In Coates and Cameron 74-93, 1989.

Coates, J. and D. Cameron, eds. Women in Their Speech Communities. Harlow: Longman, 1989

Fraser, B. Perspectives on politeness. Journal of Pragmatics 14, 219-236. 1990.

Goffman, E. Interactional Ritual: Essays on Face-to-Face Behavior. Doubleday and Co, 1967.

Holmes, J. “Women's Talk in Public Contexts”. Discourse and Society 3, 131-150, 1992.

-----. An Introduction to Sociolinguistics. Longman Group, 1992.

-----. Men, Women and Politeness. London: Longman, 1995.

Lakoff, R. Language in Context. Language. 48,907-927, 1972.

----. Language and Woman's Place. Harper \& Row, 1975.

Meyer, F. Meyer. Introducing English Linguistics. Cambridge University Press, 2009.

Shokhikhatul Khasanah

Sociolinguistics Background Determining

Linguistic Politeness
(28)

$$
\begin{array}{r}
\text { http://e-journal.ikhac.ac.id/index.php/alsuna } \\
\text { https://doi.org/10.31538/alsuna }
\end{array}
$$


Spolsky, Bernard. Sociolinguistics. Oxford University Press, 1998.

T bell, Roger. Sociolinguistics. Goals, Approaches and Problems. Bill-ing and Sons Ltd. 1976.

Trudgill, Peter. Sociolinguistics: An Introduction. Hazell Watson \& Viney Ltd, 1974.

Wardhaugh, Ronald. An Introduction to Sociolinguistics. Massachusetts: Black well Publisher. Inc, 2002.

Shokhikhatul Khasanah

Sociolinguistics Background Determining

Linguistic Politeness
ALSUNA Vol. 2 (1), 2019

(29) http://e-journal.ikhac.ac.id/index.php/alsuna https://doi.org/10.31538/alsuna 